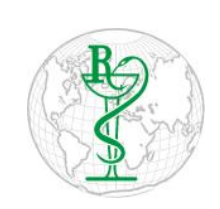

INDO GLOBAL JOURNAL OF

PHARMACEUTICAL SCIENCES

ISSN 2249- 1023

\title{
Studies on Antagonistic Actinomycetes from rhizosphere of Casuarina
}

\author{
Kulkarni Abhijit ${ }^{1}$, Kulkarni Sangita ${ }^{2 *}$ \\ ${ }^{1}$ Department of Botany, Ahmednagar College, Ahmednagar (MS) \\ ${ }^{2}$ Radhabai Kale Mahila Mahavidyalaya, Ahmednagar
}

Address for Correspondence: Kulkarni Sangita, Sangitakulkarni69@gmail.com

Received:

01.02.2019

Accepted:

16.08.2019

Keywords

Actinomycetes,

Antagonism,

Phytopathogenic.
ABSTRACT: Casuarina is one of the Agroforestry plants grown for fuel and as wind breakers on sea coast. A total of 25 different Actinomycetes were isolated from the rhizosphere soil of Casuarina equisetifolia L. from different localities of Maharashtra. These included 15 species of Streptomyces, 8 species of Streptoverticillium, 2 genera of Actinomycetes. A total of 14 species were tested for antagonism including 5 species tested against pathogenic bacteria and 9 species tested against phytopathogenic fungi. The results indicated that the isolated actinomycetes produced antibiotics against phytopathogenic fungi and few human pathogenic bacteria and inhibit their growth. The soils of Casuarina are thus rich in potentially effective Actinomycetes. (C) 2019 iGlobal Research and Publishing Foundation. All rights reserved.

Cite this article as: Kulkarni, A.; Kulkarni, S. Studies on antagonistic actinomycetes from rhizosphere of Casuarina. Indo Global J. Pharm. Sci., 2019; 9(2): 87-90. DOI: http://doi.org/10.35652/IGJPS.2019.9207.

\section{INTRODUCTION}

Casuarina is member of family Casuarinaceae and it is native of Australia (Elfers, 1988). It was introduced in interior and coastal regions of India for soil reclamation and stabilizing sand dunes. The Casuarina plant shows symbiotic association with number of microorganisms.

Soil is the outermost cover of the earth surface which is the most important component of land ecosystem since it holds the nutrients required to carry out the metabolic activities of living organism. Rhizosphere is an unique environment which is inhabited by large population of microorganism. The major groups of organisms are bacteria, actinomycetes, fungi, algae and protozoa. The microorganisms occupy larger areas as the plant reaches its active growing stage and establishes in soil. The root exudates influence the microflora (Behara et. al 1979). Large amount of exudates containing sugars, amino acids, vitamins, auxins and inorganic salts are present in the rhizosphere. The studies on Streptomyces species are found to be antagonistic against phytopathogenic bacteria and fungi (A. Kulkarni, 2010).

The soils of Casuarina are rich in potentially effective microorganisms. Actinomycetes form an integral part of the soil ecosystem. These are gram +ve organisms acting as a source of several antibiotics.

The present study aims at isolation of actinomycetes from rhizopshere soils of Casuarina from different localities of Maharashtra and testing them for their antagonistic properties against pathogenic bacteria and phtopathogenic fungi.

\section{MATERIALS AND METHODS}

For selective isolation of actinomycetes, $1 \mathrm{gm}$ of soil was dried at room temperature and mixed with $0.1 \mathrm{gm}$ calcium carbonate. It was incubated for seven days at $26^{\circ} \mathrm{C}$ in water saturated environment (Tsao, et,.al. 1960) and dispersed in 10ml phenol 1: saturated water 140 (Lawrence;1956). Serial 
Indo Global Journal of Pharmaceutical Sciences, 2019; 9(2): 87-90

dilutions were made in Phenol: water solution and $0.1 \mathrm{ml}$ of each dilution was inoculated on media in petriplates. Different media were used for isolation of actinomycetes which included starch-casein Agar (Küster and Williams, 1964) and MGA - SE (Mannitol Glycerol Aspargine -Soil Extract) Agar medium (Nonomura and Ohara, 1971). The plates were incubated at $37^{\circ} \mathrm{C}$ for $8-9$ days in an incubator.

After few days of incubation the actinomycete colonies started appearing on the medium. The morphological characters such as colony colour, number and appearance were recorded. The study of spore chain morphology and spore surface was done using Scanning electron micrographs taken on LICA CAMBRIGE MICRO-SCOPE and JOEL LOW VACCUM SEM using $35 \mathrm{~mm} 120$ ASA or WO films. Actinomycetes were identified upto the generic level with the help of slide and coverslip cultures (Waksman, 1961 and Buchnan \& Gibbons, 1974). Utilization of carbon sources by them was studied using basal medium (Pridham and Gottlieb, 1948) with different carbon sources. The identification of actinomycetes up to species level include physiological and biochemical tests. Antagonistic tests of actinomycetes against bacteria and fungi were done using cross streak plate method of Huber and Watson (1966).

\section{RESULTS}

A total of 25 different actinomycetes were isolated from the rhizosphere soils of Casuarina plantations collected from different localities of Maharashtra such as Deogadh of Ahmednagar District, Ganapati Pule and Ratnagiri Sea Coast from Ratnagiri District. These include 15 species of Streptomyces, 8 species of Streptoverticillium and 2 unidentified actinomycetes. Most of the species were identified based on colour of aerial mycelium, reverse colony colour, spore chain and spore morphology, utilization of sugar and Scanning electron micrographs. This also included physiological and biochemical tests.
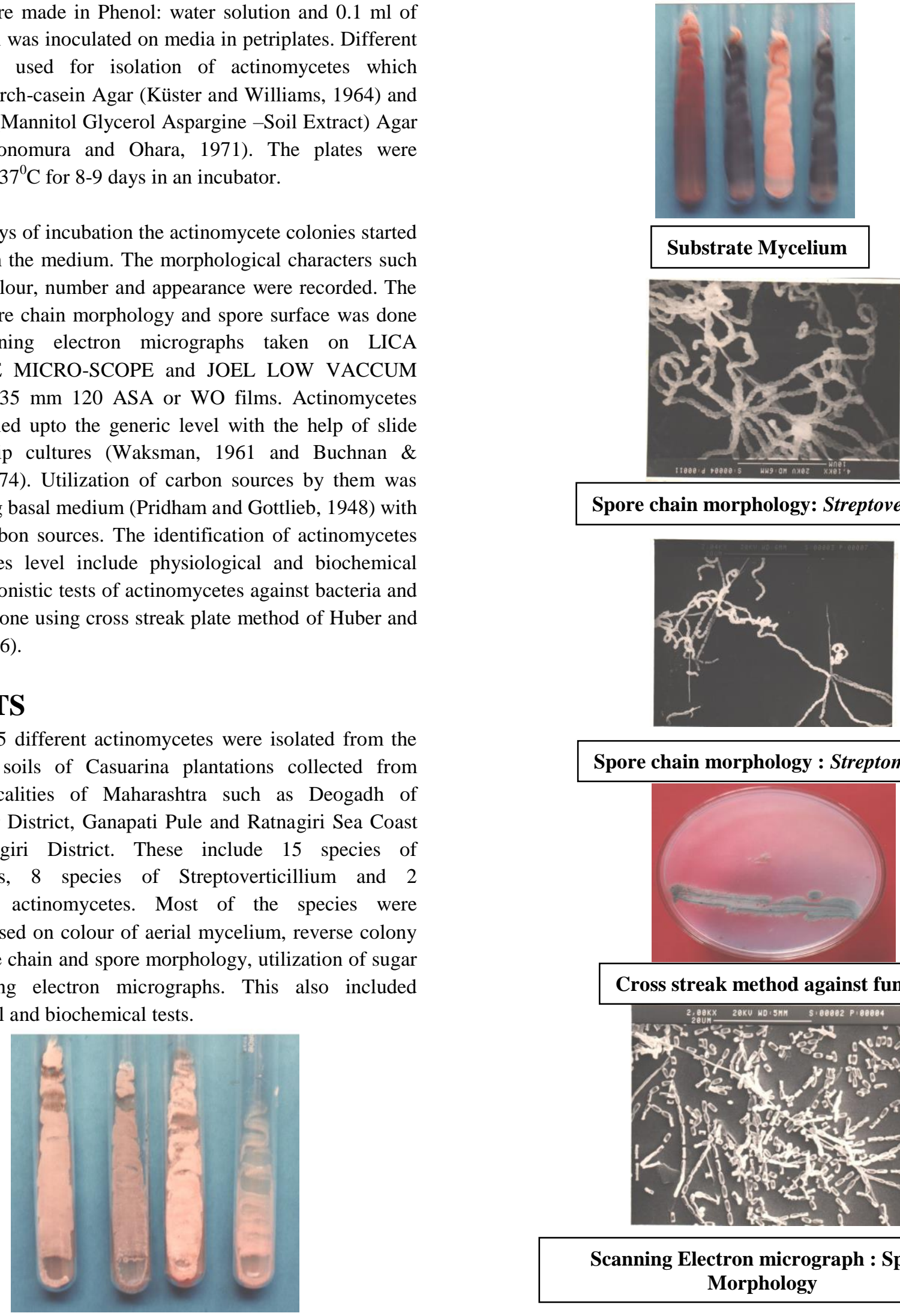

Spore chain morphology: Streptoverticillium

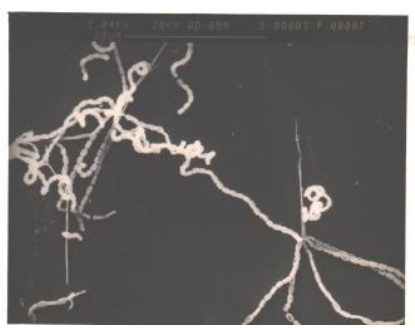

Spore chain morphology : Streptomyces

Aerial Mycelium 
Indo Global Journal of Pharmaceutical Sciences, 2019; 9(2): 87-90

Table I :Antagonism of Actinomyctes against Bacteria

\begin{tabular}{|c|c|c|c|c|c|c|}
\hline Name of the Actinomycete & \multirow{2}{*}{$\begin{array}{c}\text { Colour of } \\
\text { the } \\
\text { Colony }\end{array}$} & $\begin{array}{c}\text { Bacillus } \\
\text { subtiltis }\end{array}$ & $\begin{array}{c}\text { E. } \\
\text { coli }\end{array}$ & $\begin{array}{c}\text { Xanthom } \\
\text { os. } \\
\text { citri }\end{array}$ & $\begin{array}{c}\text { Staph. } \\
\text { aureus }\end{array}$ & $\begin{array}{c}\text { Salmone } \\
\text { lla. } \\
\text { paratyph } \\
\text { ii. }\end{array}$ \\
\hline $\begin{array}{c}\text { Streptomyces } \\
\text { chattanoogensis Bur \& Holt }\end{array}$ & $\mathrm{Br} / \mathrm{Br}$ & ++ & ++ & -- & -- & -- \\
\hline $\begin{array}{c}\text { Streptomyces } \\
\text { olivaciscleroticus } \text { Prid }\end{array}$ & G/B & ++ & -- & ++ & -- & -- \\
\hline $\begin{array}{c}\text { Streptomyces } \\
\text { violaceochromogenes }\end{array}$ & G/G & ++ & -- & -- & -- & -- \\
\hline Actinomycete (01) & W/W & ++ & ++ & ++ & ++ & ++ \\
\hline Actinomycete $(02)$ & & ++ & ++ & ++ & ++ & ++ \\
\hline
\end{tabular}

Br/Br: Brown/Brown, G/B: Grey/Black, G/G: Grey/Grey, $\quad$ W/W: White/White

Table II: Antagonism of Actinomyctes against Phytopathogenic Fungi

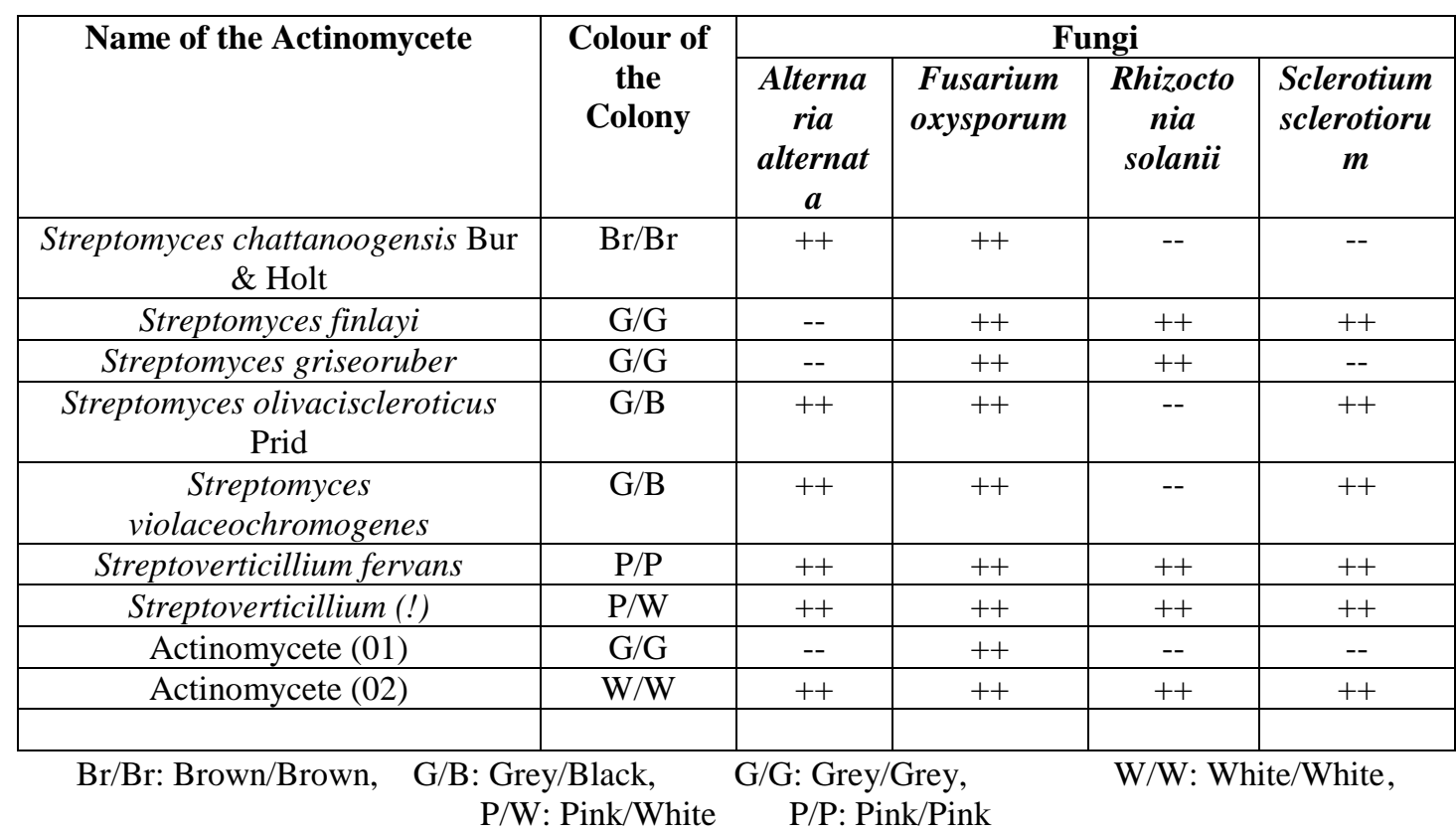

Out of the four groups of actinomycetes isolated, few were tested for antagonism against bacteria and fungi (Table I \& II). It was observed that the test organism Bacillus subtilis was inhibited by all antagonistic actinomycetes whereas the growth of Escherichia. coli was suppressed by Streptomyces chattanoogensis and Actinomycete $1 \&$ \& 2 The phytopathogenic bacteria Xanthomonas citri was suppressed by $S$. olivaciscleroticus and Actinomycete $1 \& 2$ where as human pathogenic bacteria Staphylococcus aureus, Salmonella paratyphi showed no effect of all Streptomyces species but were inhibited by Actinomycete $1 \& 2$.

Five species of Streptomyces, 2 species of Streptoverticillium and 2 unidentified actinomycetes were tested for antagonism against four phytopathogenic fungi including Alternaria alternata, Fusarium oxysporum, Rhizoctonia solani and Sclerotium sclerotiorum. The Streptomyces violaciochromogenes,. Streptoverticillium fervans and Actinomycete 2 were antagonistic to all phytopathogenic fungi. The Streptoverticillium 1 inhibited the growth of Fusarium oxysporum alone. The Streptomyces olivaciscleroticum anagonised all fungi except Rhizoctonia solani whereas Streptomyces finlayi inhibited the growth of Fusarium oxysporum, Rhizoctonia solani and Sclerotium sclerotiorum.

Actinomycete 1 showed antagonism against Fusarium oxysporum and Sclerotium sclerotiorum. S. chattanoogensis showed antagonism against Alternaria alternata and Fusarium oxysporum. 


\section{Indo Global Journal of Pharmaceutical Sciences, 2019; 9(2): 87-90}

\section{DISCUSSION AND CONCLUSION}

The result of primary screening of the active actinomycetes isolated from mine soil samples collected from Salem, Tamilnadu and Casuarina soil samples were found to be active against gram +ve bacteria Staphylococcus aureus and Escherchia coli (A. Kulkarni 2010 ; L. Ashok Kumar et. al.2012).

The results of the present investigation were correlated with the previous work and clearly indicates that all the tested actinomycetes produced antibiotics which were active against the bacteria and fungi. These organisms can be scaled up for large scale production and can be helpful in medicine.

\section{REFERENCES}

[1] Abhijit Kulkarni Colony characters and Antagonism of Sptreptomyces against bacterial and fungal pathogens, Bioinfolet 2010; 7(2) pp. 153-155.

[2] Buchnan R.E, and N.E Gibbons (Ed.). Bergey's manual of Determinative Bacteriology, $8^{\text {th }}$ ed. The Williams and Wilkins Co., Baltimore. 1974.

[3] Elfers, Susan C . Casuarina equisetifolia Unpublished papers for The Nature Conservancy on Australian pine. The Nature Conservancy : 14 P ; 1988.

[4] Huber D.M, and R.D Watson . How valid is the Agar plate inhibition test for determining antagonism between soil microorganisms? Phytopath 1966; 56: 882

[5] Küster, E.. Outline of comparative study of criteria used in characterization of the actinomycetes. Int. Bull. Bacterial.Nomenclature taxon 1959; 9: 97- 104

[6] Küster, E. and Williams S.T.. Selection of media for isolation of streptomyces. Nature Lond. 1964; 202: 928.

[7] L. Ashok Kumar, R. Balaguru Nathan, P. Palanivel and Dee Jagadeesh kumar. Studies on Antimicrobial activity of Actinomycetes against MDR wound bacterial isolates. Int. J. Appl. Bio. Pharm. Tech. 2012; 3 (4). Pp. 118123.

[8] Lawrence, C.H.. A method of isolating actinomycetes from scabby potato tissue and soil with minimum contamination. Can . J. Bot. 1956; 34 : 42-47.

[9] Nonomura, H. and Ohara, Y. Distribution of Actinomycetes in soil XI. Some new species of the genus Actinomadura Lechevalier et al. Jour. Ferment. Techno. 1971; 49: 904-912.

[10] Pridham T.G., and D. Gottleib. The utilization of carbon compounds by some actinomycetales as an aid for species determination. J. Bacteriol. $1948 ; 56: 107-114$

[11] Tsao, P.H., C. Leben and G.W. Keitt.. An enrichment method for isolating actinomycetes that produce diffusible antifungal antibiotics. Phytopath. 1960; $50: 88-89$.

[12] Waksman, S.A. The Actinomyces . Volume 2. Classification, identification and description of genera and species. The Williams and Wilkins co., Baltimore 1961.

Indo Global Journal of Pharmaceutical Sciences( ISSN 2249 1023; CODEN- IGJPAI; NLM ID: 101610675) indexed and abstracted in CrossRef (DOI Enabling), UGC CARE Journal List, EMBASE(Elsevier), National Library of Medicine (NLM) Catalog, ResearchGate, Publons, CAS (ACS), Index Copernicus, Google Scholar and many more. For further details, visit http://iglobaljournal.com

This is a special issue as an outcome of 'International Conference on Recent Advances in Traditional Medicine, Medicinal Plants and Phytochemistry' jointly organized by Ahmednagar College, India and AIMST University, Malaysia. Relaxation offered in journal format. 